\title{
PENGARUH WAKTU TAHAN DAN PENAMBAHAN KADAR GARAM DAPUR (NaCl) DALAM MEDIA PENDINGIN AIR PADA PROSES HARDENING TERHADAP SIFAT MEKANIK DAN STRUKTUR MIKRO BAJA KARBON RENDAH
}

\author{
Richard A. M. Napitupulu, Suriady Sihombing, Jonner Togatorop \\ Program Studi Teknik Mesin, Universitas HKBP Nommensen, Medan 20234 \\ richard_alf@yahoo.com
}

\begin{abstract}
This study aims to determine the effect of salt $(\mathrm{NaCl})$ in water cooling media with different levels of $10 \%, 16 \%$ and $25 \%$ against the hardness level of low carbon steel tested with Vickers after hardening in the hardening process and to determine the proportion of media which coolant produces the highest hardness from the use of water cooling media which is added to different levels of $\mathrm{NaCl}$.

The independent variable in this study is the amount of salt $(\mathrm{NaCl})$ dissolved in water cooling media with different percentages, namely $10 \%, 16 \%$ and $25 \%$. While the dependent variable is the value of the hardness of the material tested with Vickers. Hardness in the hardening process with water cooling media which added different salt $(\mathrm{NaCl}), 10 \%, 16 \%$ and $25 \%$ is 185.02 VHN, 229 VHN and 284 VHN. From the results of the study it was found that there was an effect of the salt content $(\mathrm{NaCl})$ in the water cooling media on the level of hardness in the hardening process of low carbon steel. Higher level of salt will increase value of hardness. The highest hardness was achieved in cooling media with a concentration of $25 \% \mathrm{NaCl}$ that is equal to 284 VHN followed by cooling media with a concentration of $16 \% \mathrm{NaCl}$ of $229 \mathrm{VHN}$ and the lowest was a cooling medium with a concentration of $10 \% \mathrm{NaCl}$ of $185.02 \mathrm{VHN}$.
\end{abstract}

Keywords : Holding Time, Salt (NaCl), Quenching, Mechanic Properties, Low carbon

\section{PENDAHULUAN}

Pada bagian-bagian mesin sering dijumpai suatu bahan yang memerlukan kekerasan dan keliatan, sebagai contoh sproket. Pada sproket diperlukan suatu permukaan yang keras sedang inti tetap liat [1]. Pada sprocket dapat mengalami kerusakan berupa gigi patah, aus permukaannya, serta tergores permukaannya. Untuk mendapatkan suatu konstruksi bahan yang keras, maka dapat dilakukan suatu proses pengerasan bahan (Hardening). Hardening dapat diartikan sebagai pemanasan bahan hingga suhu auatenisasi dan didinginkan dengan cepat [2].

Baja adalah besi karbon campuran logam yang dapat berisi konsentrasi dari element campuran lainnya, ada ribuan campuran logam lainnya yang mempunyai perlakuan bahan dan komposisi berbeda. Sifat mekanis adalah sensitif kepada isi dari pada karbon, yang mana secara normal kurang dari 1,0\%C. Sebagian dari baja umum digolongkan menurut konsentrasi karbon, yakni ke dalam rendah, medium dan jenis karbon tinggi. Baja merupakan bahan dasar vital untuk industri. Besi baja menduduki peringkat pertama di antara barang tambang logam dan produknya melingkupi hampir 90\% dari barang berbahan logam. Menurut Amanto 1999, kadar karbon dalam baja sekitar 0,1 - 1,7 \% sedangkan unsur lain dibatasi persentasenya [3]. Persentase dari unsur-unsur tersebut sangat mempengaruhi sifat dasar dari logam baja yang dihasilkan.

Menurut penggunaannya besi dan baja diklasifikasikan menjadi: baja konstruksi, baja mesin dan baja perkakas dan baja yang dipakai dalam penelitian ini adalah baja karbon rendah $[3,4]$. Untuk memperbaiki sifat- sifat tekniknya maka baja karbon rendah perlu mendapatkan 
perlakuan panas (heat treatment). Untuk mengubah nilai kekerasan cara yang digunakan adalah dengan salah satu perlakuan panas yang sering disebut dengan proses hardening atau pengerasan. Proses pengerasan (hardening) dilakukan pada logam, biasanya dilakukan untuk memperoleh sifat tahan aus yang tinggi dan mendapatkan kekerasan yang lebih tinggi, atau kekuatan (fatigue limit/strength) yang lebih baik [5]. Pengerasan merupakan salah satu proses perlakuan panas, dimana baja dipanaskan pada suhu tertentu diatas temperatur kritis dan kemudian ditahan sampai beberapa lama[6]. Kemudian didinginkan atau dicelup kedalam air, larutan garam tergantung pada tipe baja tersebut. Pengerasan dilakukan dengan memanaskan baja sampai ke daerah austenit lalu mendinginkanya dengan cepat, dengan pendinginan yang cepat ini terbentuk martensit yang kuat. Kekerasan maksimum yang dapat dicapai tergantung pada kadar karbon dalam baja.

Permasalahan-permasalahan yang mungkin timbul dari adanya proses perlakuan panas pada baja karbon rendah adalah: bagaimanakah pengaruh suhu pada proses hardening terhadap tingkat kekerasan Vickers [6], apakah waktu pendinginan mempengaruhi proses hardening [7], apakah proses pengerjaan awal benda kerja mempengaruhi tingkat kekerasan baja karbon rendah setelah dikeraskan dan apakah ada perbedaan nilai kekerasan dengan menggunakan media pendingin air yang ditambah garam dapur $(\mathrm{NaCl})$ dengan kadar yang berbeda-beda [8,9].

Dalam penelitian ini digunakan media pendingin air yang ditambahkan garam dapur $(\mathrm{NaCl})$ dengan kadar yang berbeda-beda. Kadar garam dapur maksimal dipilih sebesar 25\% karena dimungkinkan pada konsentrasi tersebut keadaan larutan jenuh pada temperatur kamar, dalam arti bila kadar garam dapur dinaikkan prosentasenya sudah tidak akan mempengaruhi efektifitas pendinginan karena garam dapur yang terkandung dalam larutan akan mengendap. Hal ini diperkuat dengan pendapat dari Zuh dan Kun (1988), yang menyatakan bahwa larutan garam dapur akan jenuh pada konsentrasi sebesar 25\%, dan untuk mengerti secara pasti ada tidaknya pengaruh perlakuan yang diberikan, maka dilakukan pengujian kekerasan dengan uji kekerasan Vickers. Air dipakai sebagai media pendingin karena air dapat menurunkan suhu dengan cepat yang diikuti dengan penurunan suhu di dalam benda tersebut, sehingga diperoleh lapisan yang keras yang lebih merata. Garam dapur ( $\mathrm{NaCl})$ mampu meningkatkan laju pendinginan apabila dilarutkan dalam air. Berdasarkan pemikiran diatas, maka diadakan penelitian untuk melihat pengaruh penambahan kadar garam dapur $(\mathrm{NaCl})$ dalam media pendingin air pada proses hardening terhadap sifat mekanik dan struktur mikro baja karbon rendah ”.

\section{METODE PENELITIAN}

\subsection{Bahan}

Bahan yang digunakan dalam penelitian ini adalah baja karbon rendah yang penjualannya berbentuk besi plat. Spesimen yang dipakai sebagai benda kerja yaitu tebal 6 $\mathrm{mm}$, panjang $100 \mathrm{~mm}$, lebar $50 \mathrm{~mm}$. Jumlah benda uji secara keseluruhan adalah 13 buah dengan perincian: untuk pendinginan air ditambah $10 \% \mathrm{NaCl} 3$ buah, pendinginan air ditambah $16 \% \mathrm{NaCl} 3$ buah, pendinginan air ditambah 25\% 3 buah, 3 buah untuk pendinginan air dan asli 1 buah.

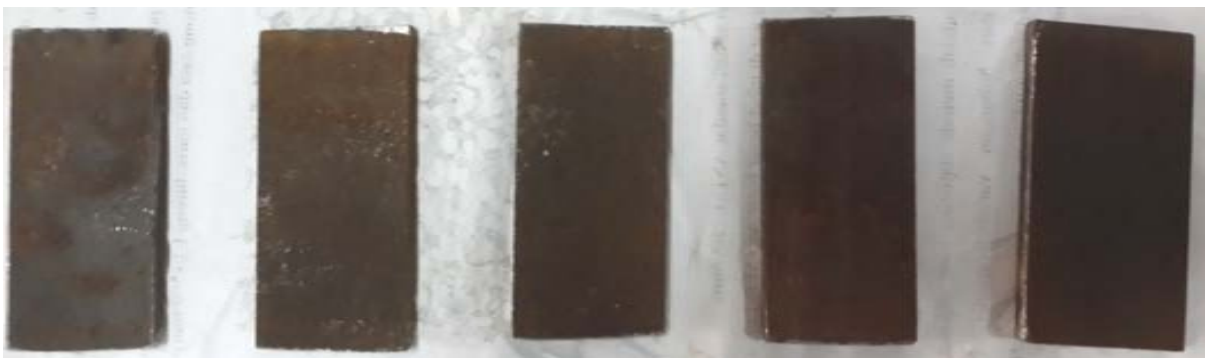

Gambar 1. Bentuk spesimen 
Tabel 1. Hasil Uji Komposisi Baja Karbon Rendah

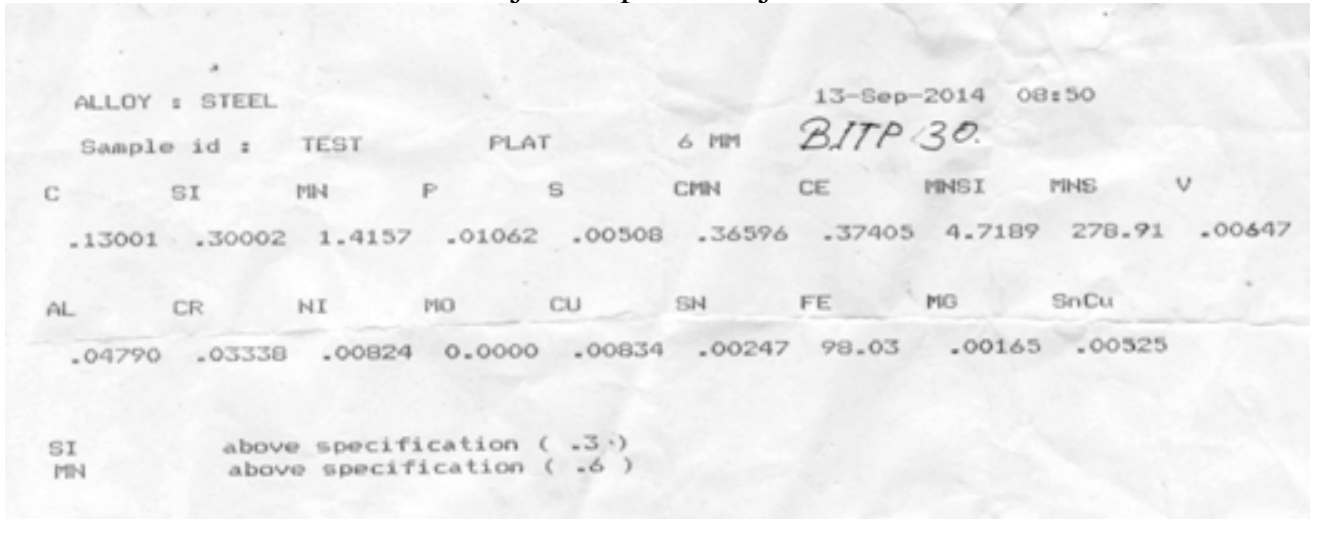

\subsection{Prosedur Penelitian}

Sampel yang telah dipotong dipanaskan ke dalam dapur pemanas sampai suhu $950{ }^{\circ} \mathrm{C}$ dan ditahan dengan variasi waktu 20, 40 dan 60 menit untuk masing-masing sampel. Kemudian, sampel dikeluarkan dari dapur dan didinginkan dengan cepat dengan mencelupkan sampel ke dalam larutan air garam ( $\mathrm{NaCl})$ masing-masing dengan konsenntrasi 10\%, 16\% dan 25\%. Kemudian sampel yang telah dicelup ke dalam larutan air garam di bersihkan dan dikeringkan. Setelah itu dilakukan pengujian kekerasan dan mikro struktur.

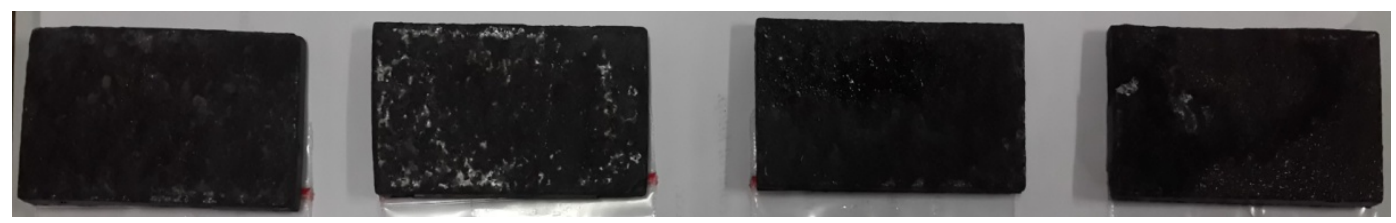
(a) pendingin air
(b) $10 \% \mathrm{NaCl}$
(c) $16 \% \mathrm{NaCl}$
(d) $25 \% \mathrm{NaCl}$

Gambar 2. Spesimen setelah didinginkan dalam air biasa dan air garam.

\section{HASIL DAN PEMBAHASAN}

\subsection{Hasil}

Data yang dihasilkan dari penelitian ini berupa angka dan grafik yang meliputi pengujian kekerasan dan pengamatan foto mikro pada material baja karbon rendah.

\subsubsection{Uji Kekerasan}

Pengujian kekerasan menghasilkan data harga kekerasan dari setiap specimen untuk lima titik penekanan sebagaimana diperlihatkan pada tabel 2 dibawah ini :

Tabel 2. Data Pengujian Kekerasan Penelitian

\begin{tabular}{|c|c|c|c|c|c|}
\hline \multirow[b]{2}{*}{ No } & \multirow{2}{*}{$\begin{array}{c}\text { Media } \\
\text { Pendingin }\end{array}$} & \multirow{2}{*}{$\begin{array}{c}\text { Waktu Tahan } \\
\text { (mnt) }\end{array}$} & \multicolumn{3}{|c|}{ Rata-rata } \\
\hline & & & d1 $(\mu \mathrm{m})$ & $\begin{array}{c}\mathrm{d} 2 \\
(\mu \mathrm{m})\end{array}$ & $\begin{array}{c}\text { kekerasan } \\
(\mathrm{VHN})\end{array}$ \\
\hline \multirow[t]{3}{*}{1} & \multirow[t]{3}{*}{ Air } & 20 & 150.8718 & 51.0680 & 223.8 \\
\hline & & 40 & 74.7033 & 76.3693 & 176.96 \\
\hline & & 60 & 74.7840 & 75.1833 & 174.94 \\
\hline \multirow[t]{3}{*}{2} & \multirow{3}{*}{$\begin{array}{c}\text { Larutan } \mathrm{NaCl} \\
10 \%\end{array}$} & 20 & 72.0131 & 69.5810 & 185.02 \\
\hline & & 40 & 72.5758 & 74.3061 & 171.96 \\
\hline & & 60 & 71.8982 & 72.0736 & 179.14 \\
\hline
\end{tabular}




\begin{tabular}{|c|c|c|c|c|r|}
\multirow{2}{*}{ No } & \multirow{2}{*}{$\begin{array}{c}\text { Media } \\
\text { Pendingin }\end{array}$} & \multirow{2}{*}{$\begin{array}{c}\text { Waktu Tahan } \\
(\mathbf{m n t})\end{array}$} & \multicolumn{3}{|c|}{ Rata-rata } \\
\cline { 3 - 6 } & & $\mathbf{d 1}(\boldsymbol{\mu m})$ & $\begin{array}{c}\mathbf{d 1} \\
(\boldsymbol{\mu m})\end{array}$ & $\begin{array}{c}\text { kekerasan } \\
(\mathbf{V H N})\end{array}$ \\
\hline 3 & Larutan $\mathrm{NaCl}$ & 20 & 62.8655 & 64.4446 & 229 \\
\cline { 3 - 6 } & $16 \%$ & 40 & 66.3685 & 68.2198 & 203.1 \\
\cline { 3 - 6 } & & 60 & 68.0867 & 65.9087 & 206.44 \\
\hline \multirow{2}{*}{4} & Larutan NaCl & 20 & 57.2874 & 56.9910 & 284 \\
\cline { 3 - 6 } & $25 \%$ & 40 & 47.3594 & 47.6377 & 212.2 \\
\cline { 3 - 6 } & & 60 & 75.1894 & 73.8826 & 166.9 \\
\hline 5 & Spesimen Awal & 0 & 72.3580 & 73.1687 & 175.2 \\
\hline
\end{tabular}

Data hasil pengujian kekerasan pada tabel diatas lalu diolah dalam bentuk grafik seperti terlihat dibawah ini:

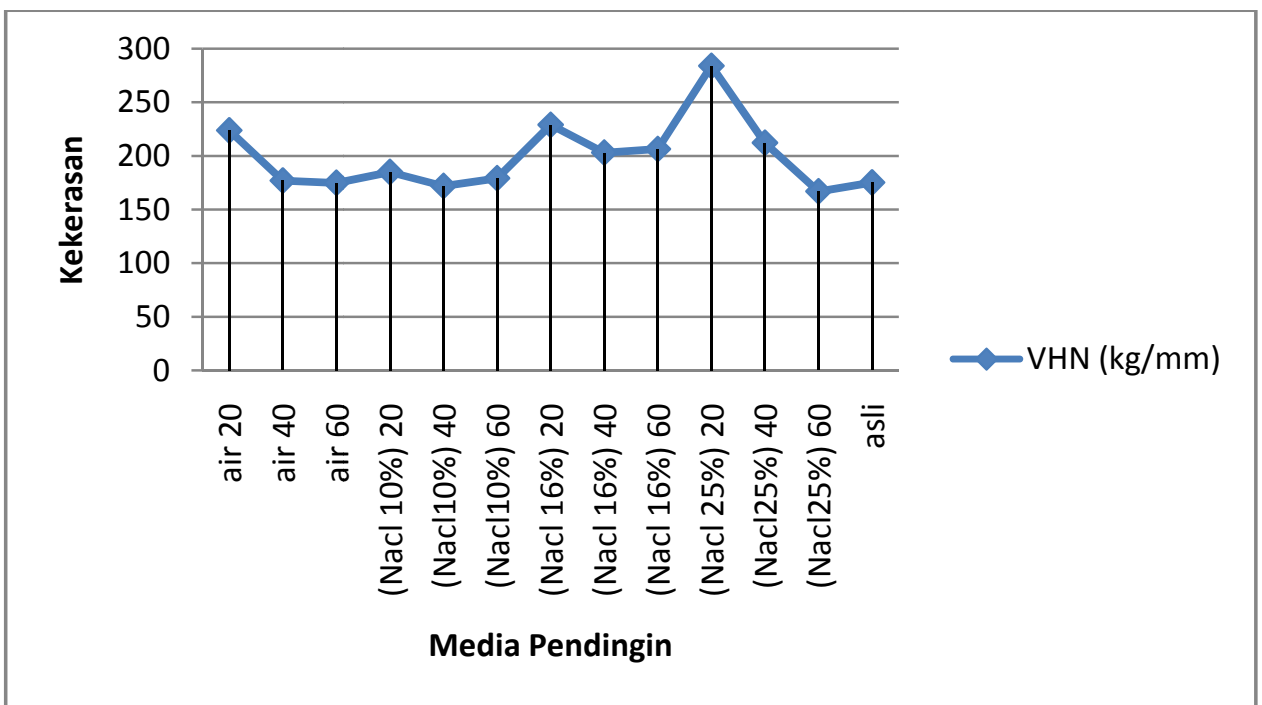

Gambar 3. Grafik rata-rata kekerasan yang terjadi untuk variasi waktu tahan dan media pendingin.

\subsubsection{Foto Struktur Mikro}

Berikut ini adalah hasil foto mikro dari eksperimen yang telah dilakukan:

a. Foto struktur mikro raw material tanpa perlakuan .

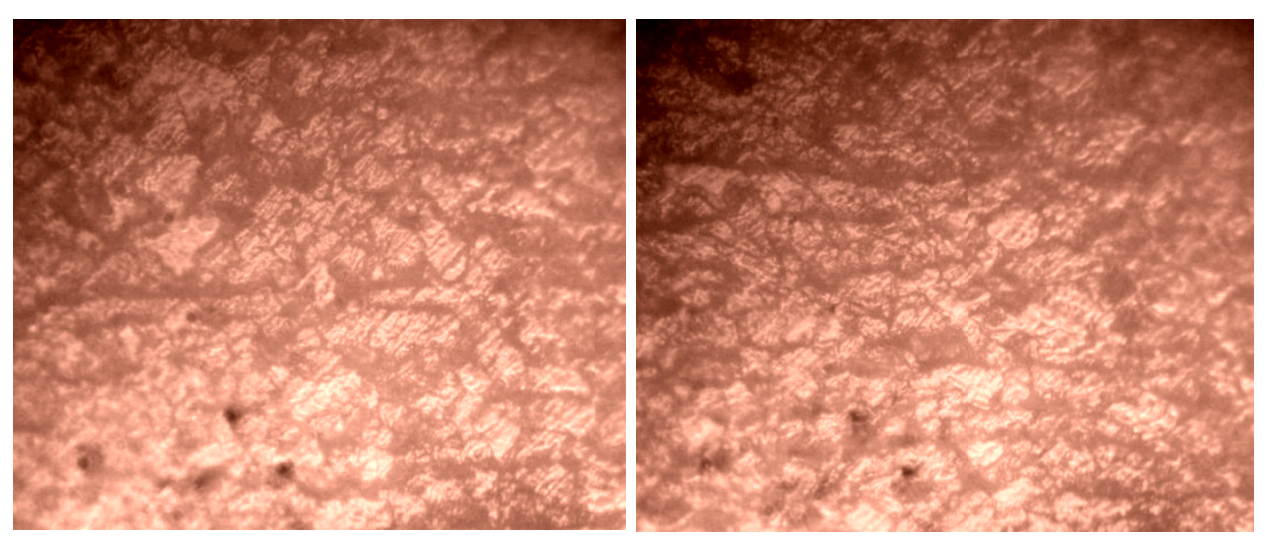

Gambar 3. Foto struktur mikro spesimen awal (400x) 
b. Gambar di bawah ini menunjukan foto struktur mikro spesimen yang didinginkan dengan air dengan variasi waktu tahan 20, 40 dan 60 menit.
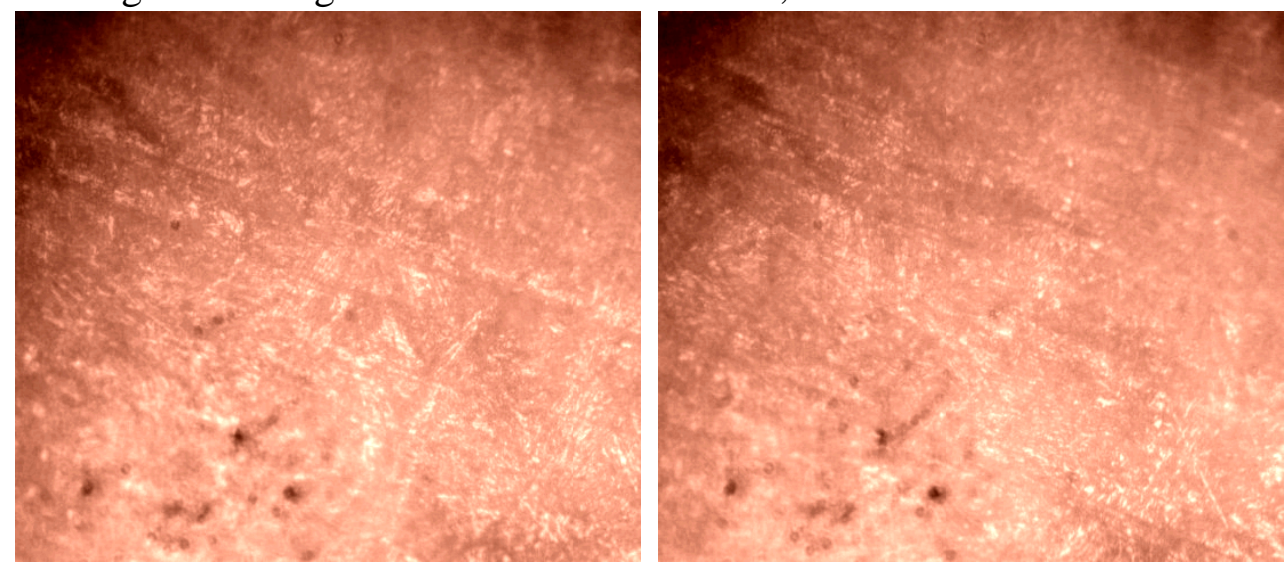

Gambar 4.a. Foto struktur mikro spesimen dengan waktu tahan 20 menit dan didinginkan dengan air (400x)
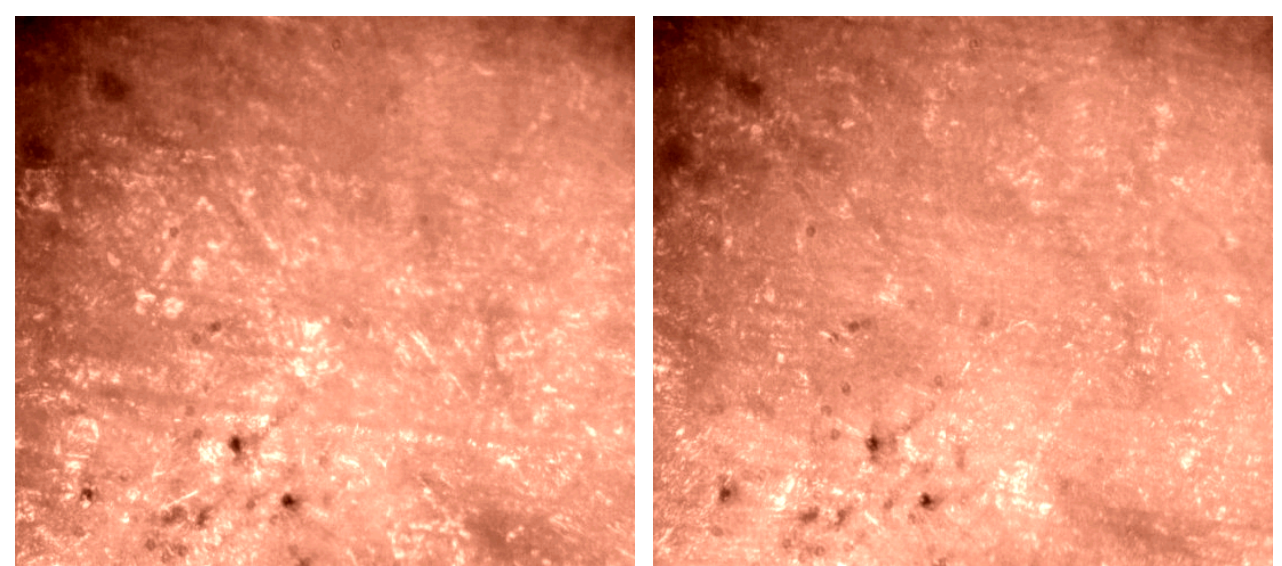

Gambar 4.b. Foto struktur mikro spesimen dengan waktu tahan 40 menit dan didinginkan dengan air (400x).
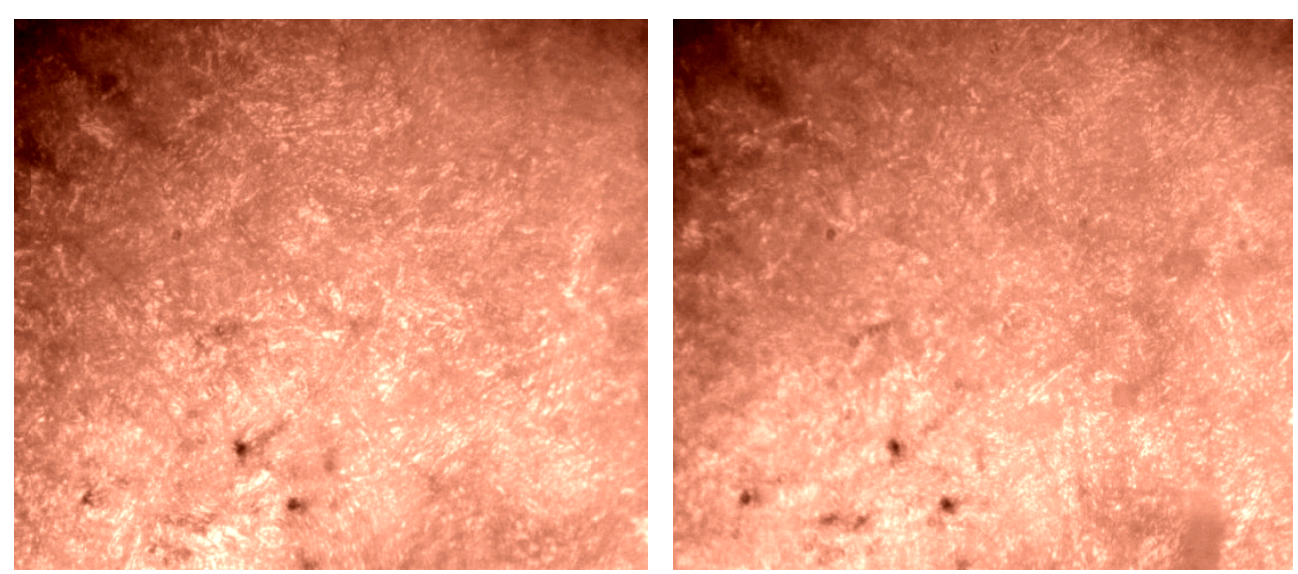

Gambar 4.c. Foto struktur mikro spesimen dengan waktu tahan 60 menit dan didinginkan dengan air (400x). 
c. Gambar di bawah ini menunjukkan foto struktur mikro spesimen yang didinginkan dengan larutan $\mathrm{NaCl}$ 10\% dengan variasi waktu tahan 20, 40 dan 60 menit.
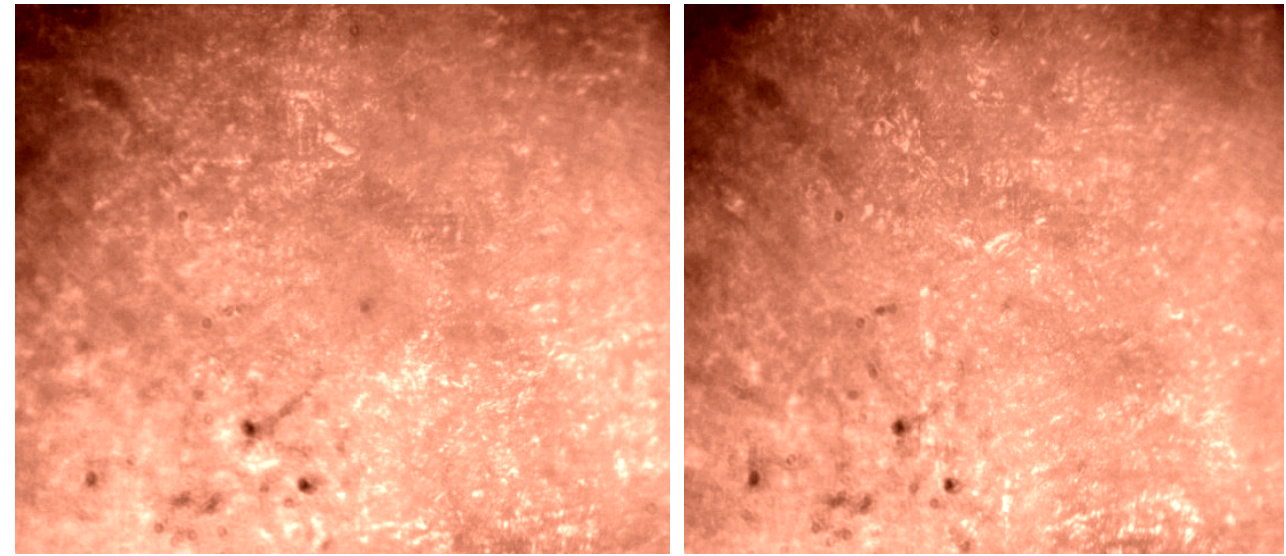

Gambar 5.a. Foto struktur mikro spesimen dengan waktu tahan 20 menit dan didinginkan dengan larutan $\mathrm{NaCl}$ 10\% (400x).
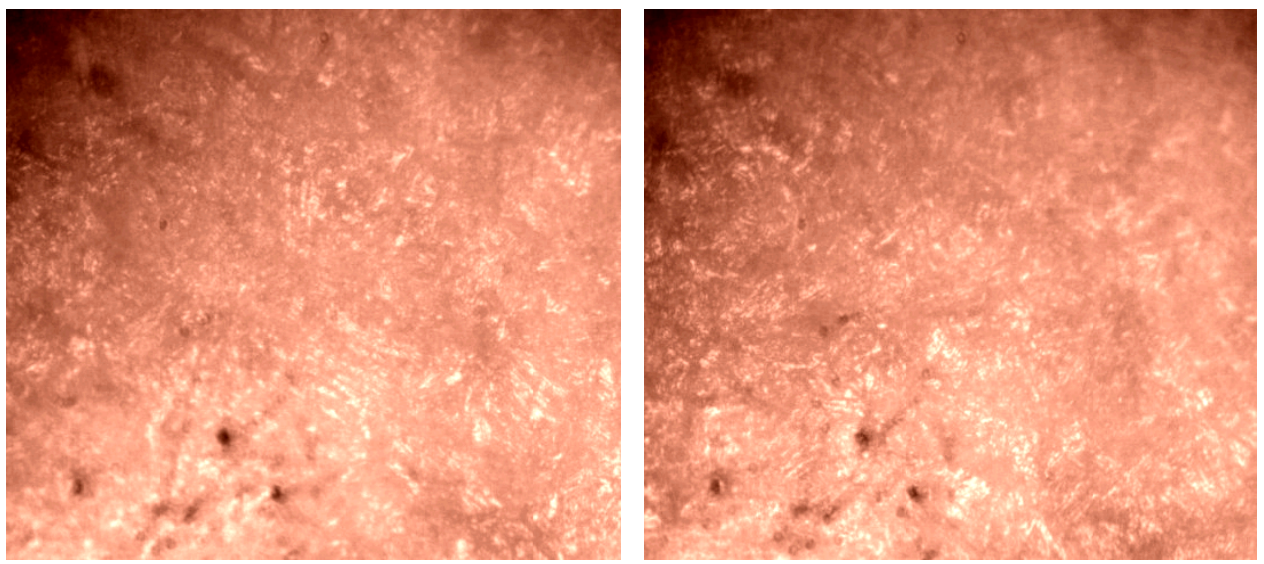

Gambar 5.b. Foto struktur mikro spesimen dengan waktu tahan 40 menit dan didinginkan dengan larutan $\mathrm{NaCl} 10 \%$ (400x).
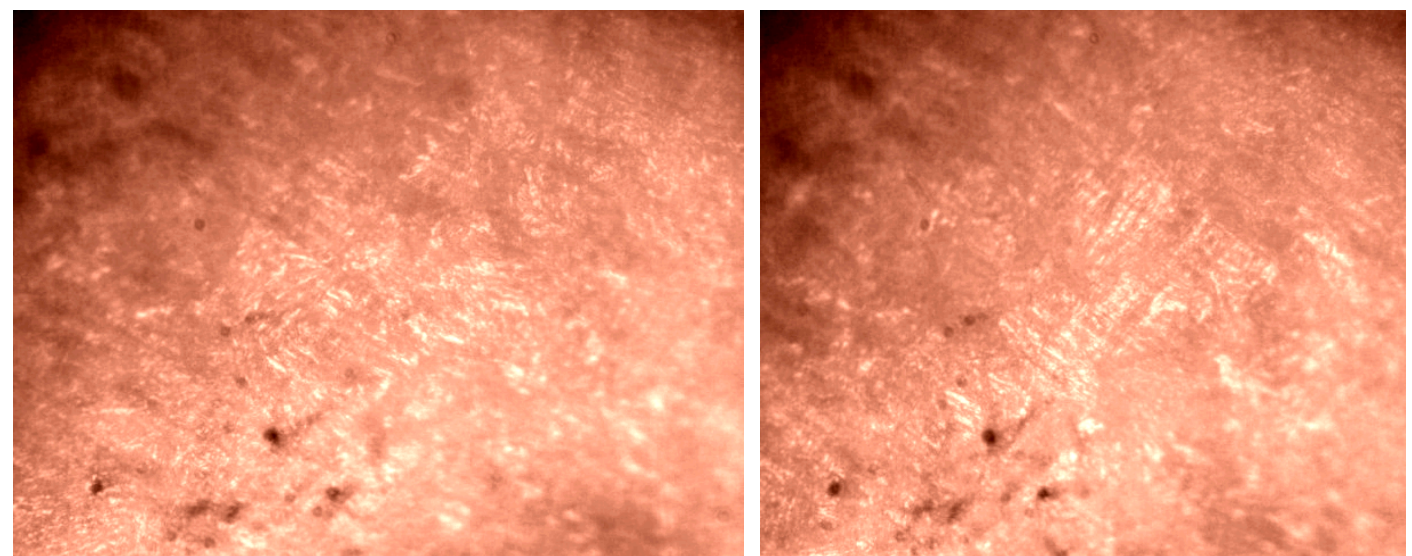

Gambar 5.c. Foto struktur mikro spesimen dengan waktu tahan 60 menit dan didinginkan dengan larutan $\mathrm{NaCl}$ 10\% (400x) 
e. Gambar di bawah ini menunjukan foto struktur mikro spesimen yang didinginkan dengan larutan $\mathrm{NaCl}$ 16\% dengan variasi waktu tahan 20, 40 dan 60 menit.
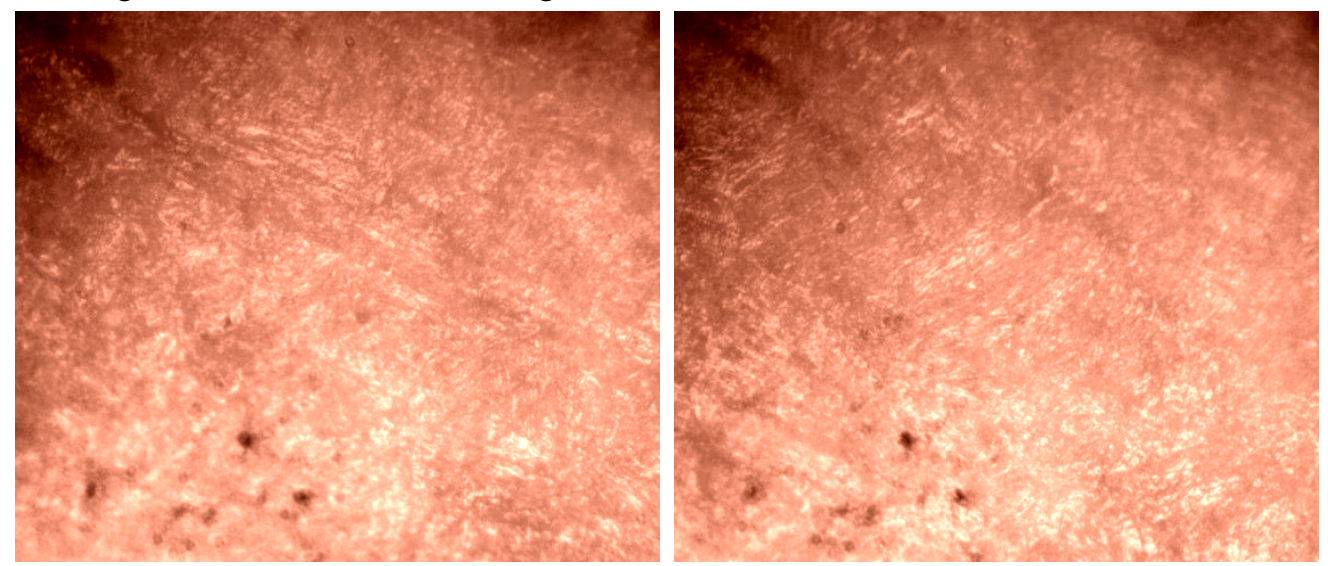

Gambar 6.a. Foto struktur mikro spesimen dengan waktu tahan 20 menit dan didinginkan dengan larutan Nacl 16\% (400x).
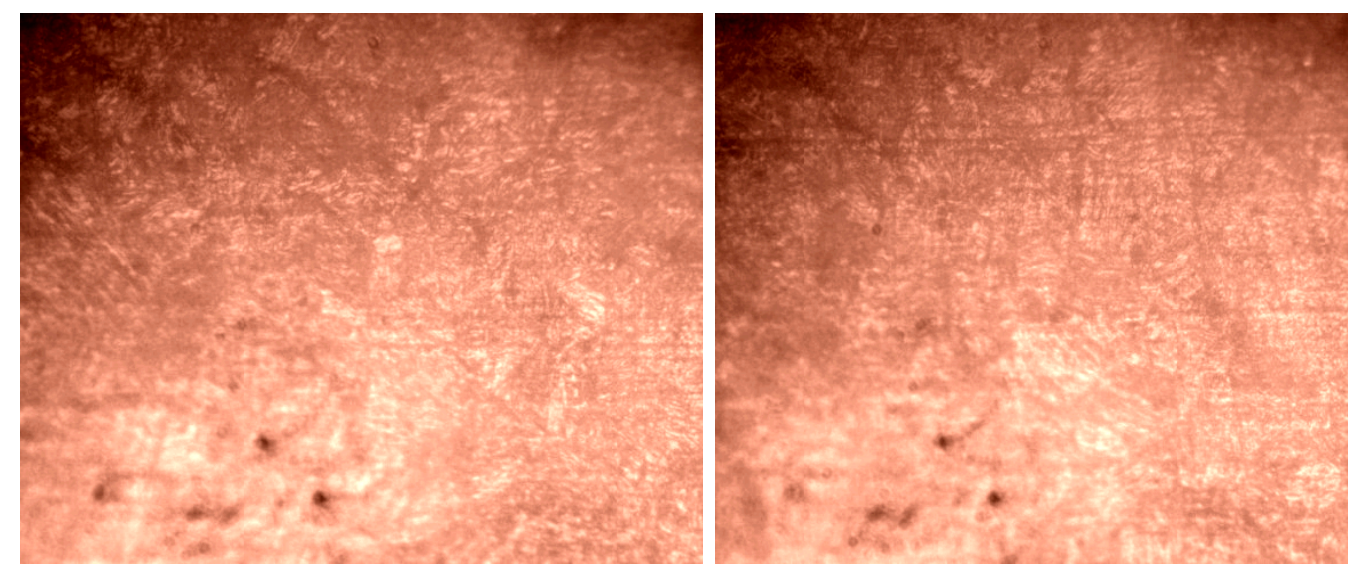

Gambar 6.b. Foto struktur mikro spesimen dengan waktu tahan 40 menit dan didinginkan dengan larutan $\mathrm{NaCl}$ 16\% (400x).
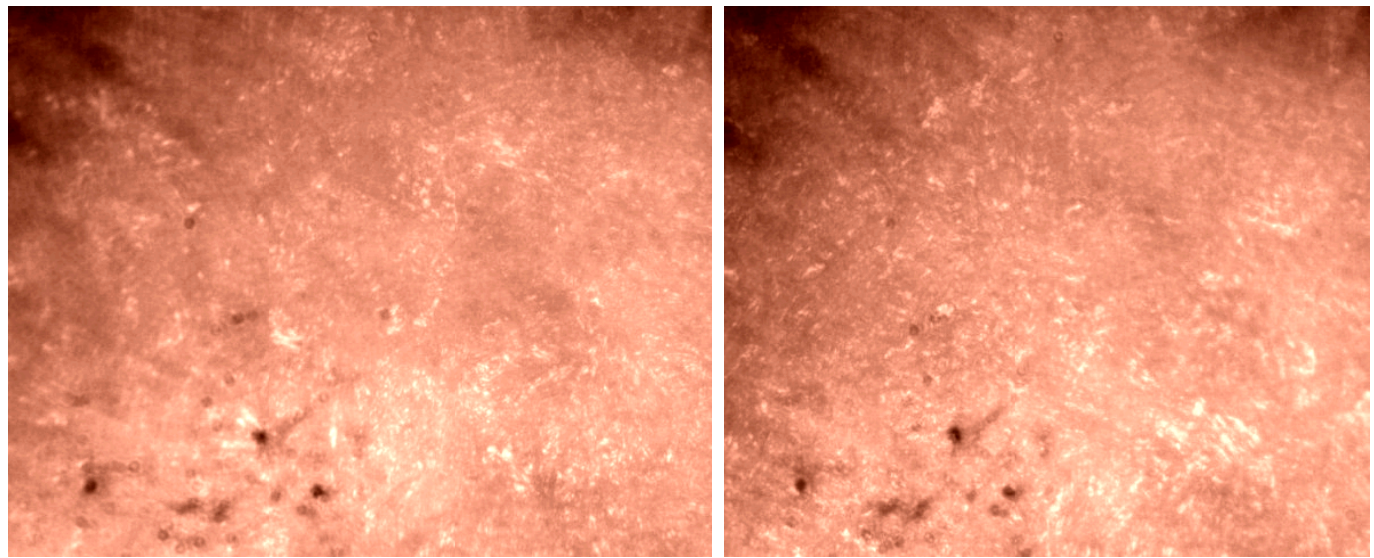

Gambar 6.c. Foto struktur mikro spesimen dengan waktu tahan 60 menit dan didinginkan dengan Nacl 16\% (400x) 
f. Gambar di bawah ini menunjukan foto struktur mikro spesimen yang didinginkan dengan larutan $\mathrm{NaCl}$ 25\% dengan variasi waktu tahan 20, 40 dan 60 menit.
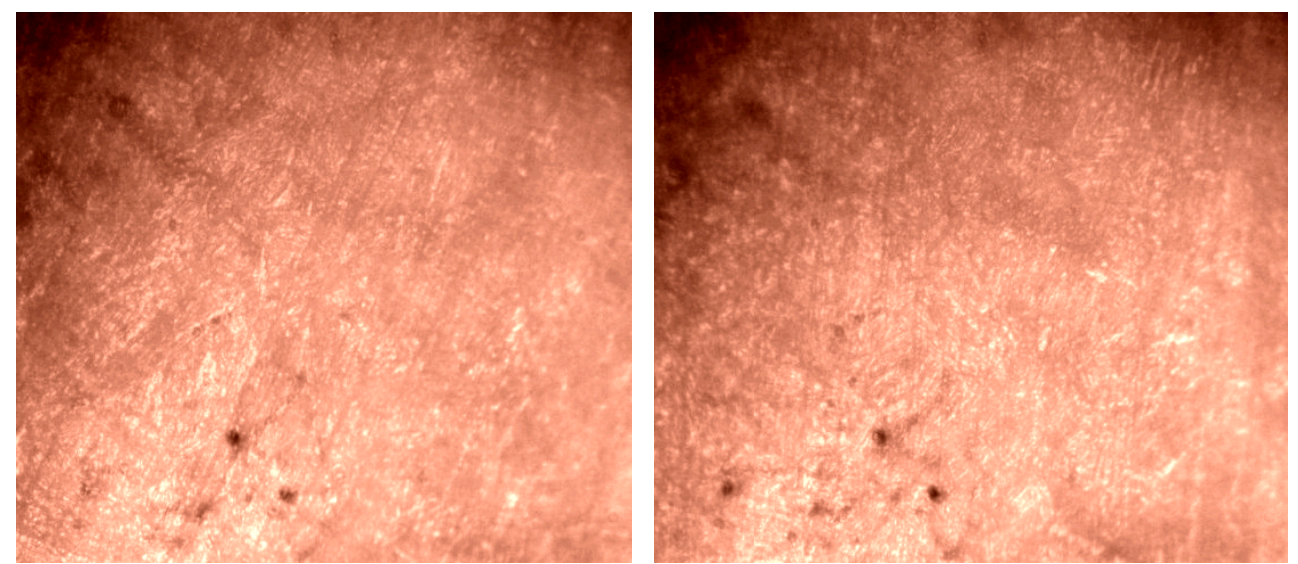

Gambar 7.a. Foto struktur mikro spesimen dengan waktu tahan 20 menit dan didinginkan dengan larutan Nacl 25\% (400x).
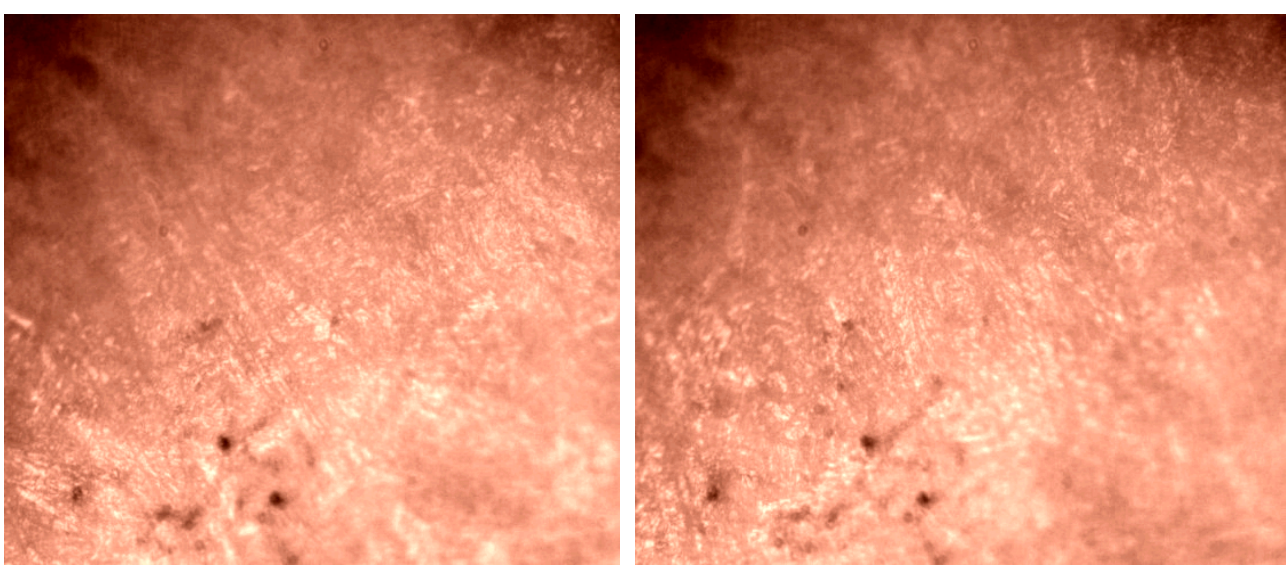

Gambar 7.b. Foto struktur mikro spesimen dengan waktu tahan 40 menit dan didinginkan dengan larutan $\mathrm{NaCl}$ 25\% (400x).
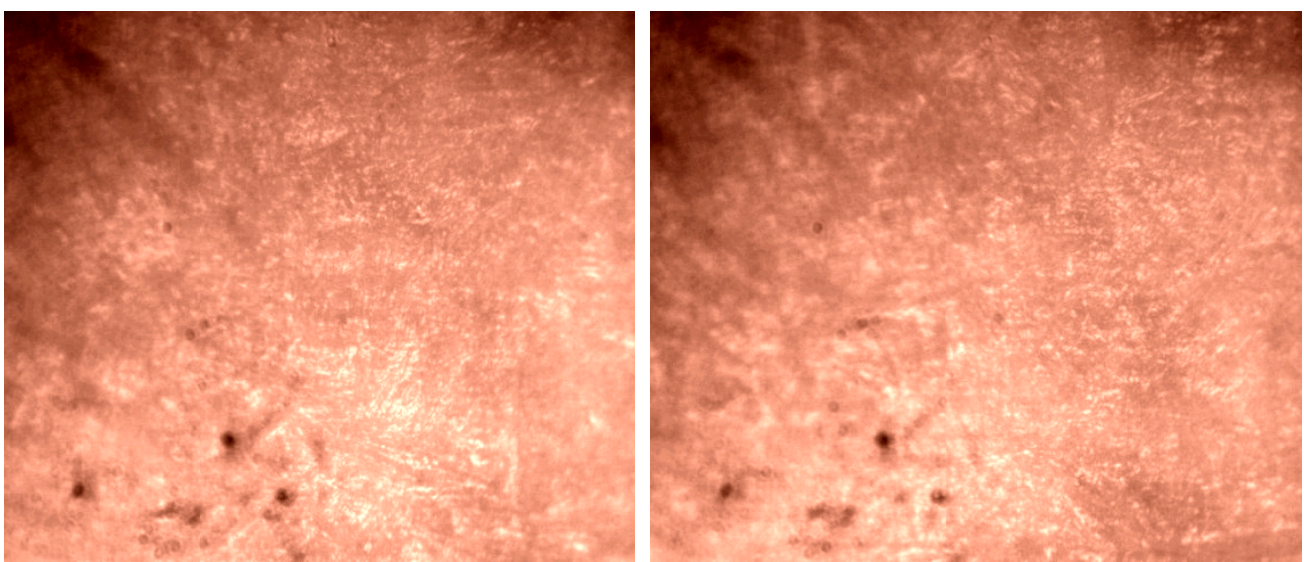

Gambar 7.c. Foto struktur mikro spesimen dengan waktu tahan 60 menit dan didinginkan dengan larutan Nacl 25\% (400x). 


\subsection{PEMBAHASAN}

Data hasil penelitian yang dideskripsikan dalam bentuk grafik seperti gambar 2 memperlihatkan pengaruh media pendingin dan konsentrasi garam terhadap kekerasan baja karbon yang sudah mengalami proses perlakuan panas. Dari gambar terlihat bahwa akan terjadi peningkatan kekerasan jika baja karbon yang telah dipanaskan dan didinginkan dengan media pendingin larutan garam dapur jika dibandingkan dengan media pendingin air. Dari grafik dapat dilihat bahwa konsentrasi larutan garam dapur yang menghasilkan kekerasan yang terbaik ada pada larutan $\mathrm{NaCl} 25 \%$. Namun jika melihat kecenderungan grafik yang terbentuk dan juga pengaruh dari pada waktu tahan, maka konsentrasi larutan garam dapur yang menghasilkan kekerasan yang terbaik ada pada larutan $\mathrm{NaCl} 16 \%$.

Jika mengacu kepada grafik, maka kita dapat melihat pengaruh waktu tahan terhadap kekerasan yang terjadi dimana waktu tahan 20 menit akan menghasilkan peningkatan kekerasan yang cukup signifikan jika dibandingkan dengan waktu tahan 40 dan 60 menit. Hal ini perlu dibuktikan dengan melihat phasa dan ukuran dari struktur mikro yang terjadi. Dari grafik terlihat bahwa kecenderungan grafik yang dibentuk pada pencelupan dengan larutan $\mathrm{NaCl} 10 \%$ dan 16\% adalah Berbeda, namun pada larutan 25\% mengalami perbedaan kecenderungan. Hal ini kemungkinan disebabkan kekurang telitian dari pengamatan data/alat ataupun mungkin oleh phasa dan ukuran struktur mikro yang terbentuk berbeda dari bentuk dan ukuran struktur mikro yang terbentuk pada larutan $\mathrm{NaCl} 10 \%$ dan $16 \%$. Untuk itu perlu dilakukan pengamatan struktur mikro lebih lanjut.

Hasil dari pengamtan struktur mikro untuk semua media pendingin (air/larutan Nacl) dapat dilihat pada gambar 3 sampai gambar 7.c. Gambar tersebut seharusnya dapat memperlihatkan struktur mikro yang terjadi. Namun karena keterbatasan alat/mikroskop optik yang ada (hanya pembesaran 400x), maka struktur mikro dari masing-masing perlakuan tidak dapat diamati secara jelas. Hal ini juga disebabkan kecilnya ukuran dari struktur mikro yang terbentuk.

Jika mengacu kepada teori, terjadinya peningkatan kekerasan disebabkan persentase struktur yang terbanyak terbentuk adalah martensit dengan ukuran yang kecil. Pada saat baja dipanaskan terbentuklah kristal-kristal berbutir halus yang seragam pada semua bagian ketika baja masih padat, karenanya disebut larutan padat (Austenit). Apabila baja dalam keadaan austenit kemudian didinginkan secara perlahan- lahan, maka akan kembali seperti semula sebelum dipanaskan. Tetapi apabila didinginkan dengan cepat maka dapat dikatakan keadaan larutan padat (Austenit) itu juga tetap berada dalam keadaan dingin sebab tidak ada waktu untuk membentuk kristal-kristal yang besar. Keadaan ini disebut martensit. Kristal martensit kecil (halus) sehingga baja mempunyai sifat sangat kuat dan keras.

Adanya kandungan $\mathrm{NaCl}$ dalam larutan berfungsi untuk meniadakan gelembung uap panas, sehingga proses pendinginan dapat berlangsung lebih cepat. Jika mengacu kepada teori, $\mathrm{NaCl}$ pada temperatur kamar akan menjadi phasa larutan jenuh pada persentase lebih besar atau sama dengan 23\%. Oleh sebab itu mungkin saja pada konsentrasi 25\% akan membuat proses peniadaan gelumbung uap panas lebih cepat sehingga proses pendinginan juga lebih cepat. Ini salah satu hal yang mungkin menyebabkan kekerasan spesimen yang dicelup pada larutan $\mathrm{NaCl} 25 \%$ memiliki kekerasan yang paling tinggi.

\section{KESIMPULAN}

Dari hasil penelitian dapat ditarik kesimpulan sebagai berikut:

1. Ada pengaruh kadar garam dapur $(\mathrm{NaCl})$ dalam media pendingin terhadap nilai kekerasan pada proses pengerasan baja karbon rendah. Semakin tinggi kadar garam dapur $(\mathrm{NaCl})$ dalam media pendingin semakin tinggi pula nilai kekerasannya.

2. Ada pengaruh waktu tahan yang menghasilkan kekerasan tertinggi dari variasi larutan $\mathrm{NaCl}$ sebagai media pendingin, dimana waktu tahan 20 menit memberikan hasil kekerasan yang terbaik untuk ketiga jenis konsentrasi larutan $\mathrm{NaCl}$.

3. Dari ketiga variasi kadar garam dapur $(\mathrm{NaCl})$ yang berbeda-beda yaitu $10 \%, 16 \%$ dan $25 \%$, yang menghasilkan nilai kekerasan yang tertinggi adalah media pendingin dengan $25 \% \mathrm{NaCl}$ sebesar $284 \mathrm{VHN}$ disusul media pendingin dengan $16 \% \mathrm{NaCl}$ sebesar $229 \mathrm{VHN}$ dan yang terendah adalah media pendingin dengan $10 \% \mathrm{NaCl}$ sebesar 185,02 VHN.

4. Pengaruh waktu tahan terhadap kekerasan yang terjadi dimana waktu tahan 20 menit akan 
menghasilkan peningkatan kekerasan yang cukup signifikan.

5. Kandungan $\mathrm{NaCl}$ dalam larutan berfungsi untuk meniadakan gelembung uap panas sehingga proses pendinginan berlangsung dengan cepat.

\section{DAFTAR PUSTAKA}

[1]. Andika Wisnuajati, Analisis perlakuan carburizing terhadap sifat fisik dan mekanik pada bahan sprocket imitasi sepeda motor, Jurnal SIMETRIS, Vol 8 No 1 April 2017

[2]. Sumiyanto, Abdunnaser, Pengaruh media pendingin terhadap sifat mekanik dan struktur mikro plat baja karbon ASTM A-36, Bina Teknika, Volume 11 No. 2, Desember 2015.

[3]. Amanto, H. dan Daryanto, 1999. Ilmu Bahan. Jakarta, Bumi Aksara

[4]. Beumer, B.J.M.,(1994), Ilmu Bahan Logam, Jilid Satu, Bharatara Karya Aksara, Jakarta.

[5]. Nasmi Herlina Sari, Perlakuan panas pada baja karbon: efek media pendinginan terhadap sifat mekanik dan struktur mikro, Jurnal Teknik Mesin (JTM): Vol. 06, No. 4, Oktober2017

[6]. Muhammad Iqbal, Pengaruh temperature terhadap sifat mekanis pada proses pengkarbonan padat baja karbon rendah, Jurnal SMARTek, Vol. 6, No. 2, Mei 2008:

[7]. Mohammad Ismanhadi S dan Yuli Setyorini, Pengaruh media pendingin pada proses hardening terhadap strukturmikro baja mangan hadfield AISI 3401 PT Semen Gresik, Jurnal Teknik POMITS Vol. 2, No. 2, (2013)

[8]. Yuliana Aziza1, Yayi Febdia Pradani, Pengaruh kadar garam dapur (NaCl) dalam media pendingin terhadap tingkat kekerasan pada proses pengerasan baja ST-60, FTIKA Unira Malang | Vol. 1 | No. 1, Oktober 2017.

[9]. Hamzah Nur, Pengaruh penggunaan media pendingin air garam, air tawar, dan air asam pada perlakuan pnas terhadap kekerasan baja ST 60, TEKNOLOGI VOL. 16 NO. 1 APRIL 2017

[10].M. Taufan Rizal, Pengaruh kadar garam dapur (NaCl) dalam media pendingin terhadap tingkat kekerasan pada proses pengerasan baja V-155, Skripsi, Jurusan Teknik Mesin FT Universitas Negeri Semarang, 2005 